O.I. Гармаш, завідувач лабораторії покрівельних і гідроізоляційних робіт ДП "НДІБВ" м. Київ

\title{
ОСНОВНІ ПОМИЛКИ ПРИ ПРОЕКТУВАННІ І ВИКОНАННІ ГІДРОІЗОЛЯЦІї ПІДЗЕМНИХ ЧАСТИН БУДИНКІВ І СПОРУД
}

\begin{abstract}
Анотащіл. У статті наведено перелік основних помилок при проектуванні, влаштуванні гідроізоляиії підземних конструкиій будівель і споруд. Проаналізовані причини появи помилок та методи іх зменшення або позбавлення від них.

Ключові слова: гідроізоляиія, дефекти гідроізоляції, протікання, гідроізоляція підвищеної надійності.
\end{abstract}

Постановка проблеми. Відомо, що зведення підземних споруд у нас в країні супроводжується великою кількістю протікання. Більш того, така ситуація перетворилася в проблему гідроізоляції для країни: витрачені фінансові, матеріальні та людські ресурси, а гідроізоляція -тече.

Мета роботи. Для вирішення проблеми необхідно проаналізувати основні ризики появи протікання гідроізоляції підземних частин будівель і споруд. Основні, це ризики:

- при проектуванні;

- при влаштуванні;

- при будівництві будівлі або споруди;

- при експлуатації.

Результати досліджень

Помилки при проектуванні гідроізоляцій. В першу чергу, вони пов'язані з відсутністю Державних будівельних норм на проектування гідроізоляцій підземних частин будівель і споруд.

Важливим являється вибір підрядника для влаштування гідроізоляції. Замовник та проектувальник при виборі підрядника повинні керуватися такими міркуваннями:

- діапазон спеціалізації.

Чим більше підрядник має досвіду з влаштування гідроізоляції з різних матеріалів (ПВХ, ЕПДМ, ТПО), тим менше ймовірність здійснення помилок 3 його боку.

\section{- відгуки та рекомендації.}

Будь-який сумлінний підрядник завжди прагне отримати відгуки і рекомендаційні листи від клієнтів після виконання їніх замовлень. Тому завжди

необхідно цікавитися не тільки інформацією про об'єкти, які виконав підрядник, але і запитувати письмове підтвердження його кваліфікації з боку інших замовників.

- обладнання.

Будь-який поважаючий себе підрядник прагне мати повний набір обладнання для виконання гідроізоляційних робіт.

- гарантія.

Добросовісний підрядник завжди дає гарантію на свої роботи, а також пропонує послугу з післягарантійного обслуговування гідроізоляції.

Поява помилок при проектуванні гідроізоляцій пов'язана з відсутністю у проектувальника повної інформації про фізико-механічні властивості нового гідроізоляційного матеріалу, оптимальних технологічних методах застосування, а також вимогами замовника неодмінно здешевити влаштування гідроізоляції.

У зв'язку з цим є два практичних підходи до

проектування гідроізоляційних систем: один - за вартістю і надійністю; інший - за вартістю і ремонтопридатності. В першому випадку на весь термін служби споруди проектується потужна, надійна, дорога гідроізоляційна система, яка може сприймати деформації, але має низьку ремонтопридатність. У другому - відносно дешева гідроізоляція, яка при незначних пошкодженнях може бути легко відремонтована.

Гідроізоляція споруд - це система, для успішного функціонування якої необхідно орієнтуватися на системний підхід при проектуванні і її створенні. Гідроізоляційна система являє собою сукупність елементів, що захищають споруди від впливу води і вологи. Частиною іiї є гідроізоляційна мембрана покриття з різних матеріалів, що наносяться в конструкцію на поверхню споруди або поза нею.

На вибір матеріалу і конструкції гідроізоляційної мембрани впливає величина передбачуваного гідростатичного тиску води, допустимої вологості повітря приміщення, агресивності середовища, деформативності основи під споруду. Особливу увагу необхідно приділити конструктивній схемі герметизації стикових з'єднань, сполучень конструкцій, введення комунікацій, деформативних швів, так як найчастіше відмова гідроізоляції відбувається в результаті деформації окремих елементів і блоків споруди або дефектів в стикових з'єднаннях.

Одна з помилок при проектуванні гідроізоляції підземних частин будівель і споруд - не враховується необхідність безперервності і герметичність гідроізоляційної системи по всій площі підземної частини. Гідроізоляція повинна бути водонепроникною i безперервною, тобто являти собою безперервний водонепроникний контур, так як один неякісний елемент може погіршити або вивести 3 ладу всю гідроізоляційну систему!

Помилки при влаштуванні гідроізоляції.

Основна причина таких помилок - спроба економити на вартості робіт. Запрошуються найнижчеоплачувані, а значить, найменш кваліфіковані робітники. $\mathrm{y}$ цьому випадку навіть кращий матеріал буде покладений неграмотно і з великою кількістю дефектів.

Помилка - це невиконання вимог проектної документації.

Помилка - це також не представлення фронту робіт, а виконання гідроізоляції окремими ділянками, часто 3 порушеннями послідовності технологічних операцій та порушенням технологічної спрямованості виконання (необхідно назустріч подачі гідроізоляційних матеріалів). 


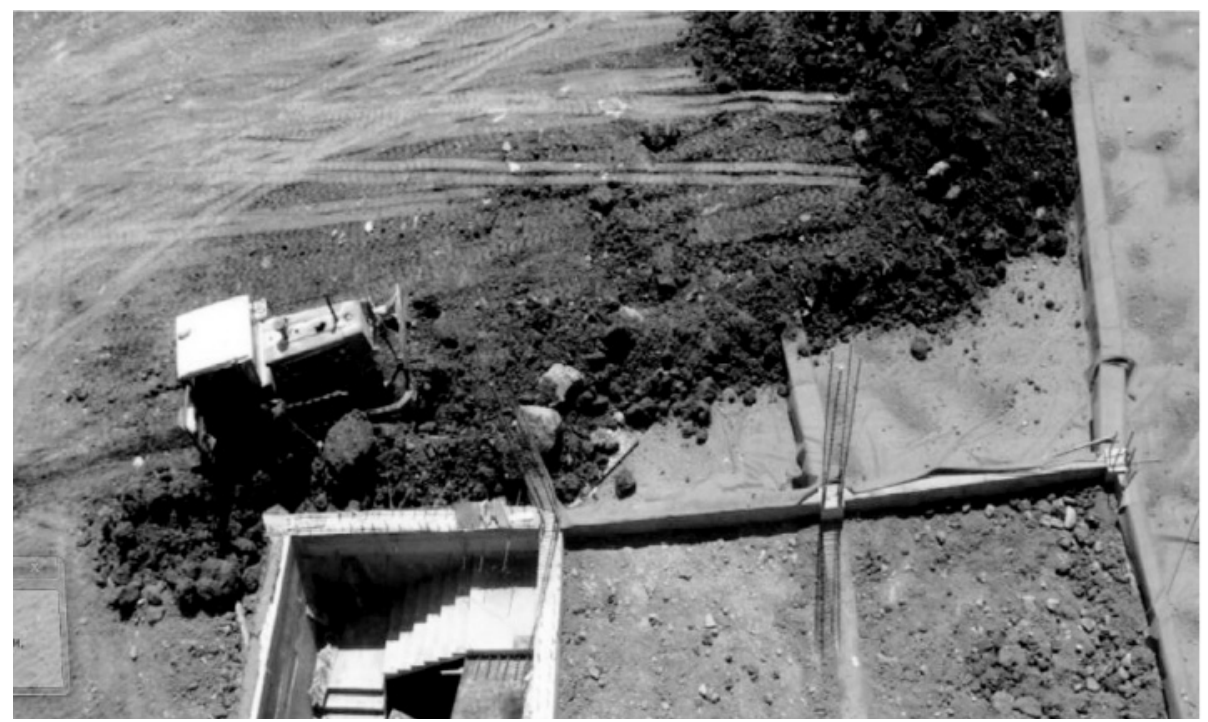

Рис. 1. Зворотна засипка виконаної гідроізоляції грунтом з включенням каменів

Найчастішою помилкою є відсутність організації контролю якості виконання гідроізоляційних робіт і приймання-здачі виконаної гідроізоляції.

Найпоширеніша помилка - механізована зворотна засипка виконаної гідроізоляції грунтів з включенням твердих, важких з відкритими краями предметів. (Рис.1)

Пошкодження гідроізоляції при будівництві будівлі або споруди.

Механічні пошкодження на вже виконаній, але не захищеній гідроізоляції з'являються дуже часто, коли при влаштуванні гідроізоляції (або після влаштування) на цій ділянці ведуться інші будівельномонтажні роботи, при цьому часто відбувається: цій;

- перетягування волоком будь-яких конструк-

- перенесення важких конструкцій;

- прохід робочих;

- складування будівельних елементів, комплектуючих, арматури (Рис.2)

- ведення зварювальних робіт;

- пробивання отворів у вже виконаній гідроізоляції (Рис.3)

Негативний ефект від вищенаведених дій може бути збільшений, якщо притягнутий до роботи сторонній субпідрядник, який не звертає належної уваги на вже змонтовані будівельні елементи.
Сдиний вихід - детальне планування будівельних робіт і виконання захисного покриття виконаної гідроізоляції.

\section{Пошкодження при експлуатації.}

Це дуже поширена причина ушкоджень. Зазвичай в процесі експлуатації гідроізоляції, коли плануються додаткові роботи по встановленню обладнання, замовник не звертається до професіоналівгідроізолювальників, а працює "швидко, своїми силами". В результаті виникають пошкодження гідроізоляції, в тому числі і дуже значні, на великій площі. Іноді пошкодження намагаються відремонтувати косметично підручними засобами. Коли це не допомагає, і власник викликає фахівців, перед ними постають результати безграмотного вандалізму: акуратно вирізані в гідроізоляції наскрізні отвори для проводів і труб, забиті через гідроізоляцію дюбелі, наслідки транспортування волоком тяжких вантажів, сліди зварювальних робіт, полімерна гідроізоляція, що залита бітумною мастикою.

Результатом відмови гідроізоляційних систем є збільшення прямих витрат на експлуатацію конструкцій (в 2-5 разів), скорочення терміну служби споруди (в 1,5-2 рази) і експлуатаційного обладнання, зміна експлуатаційного середовища всередині споруди, погіршення умов праці та зменшення прибутку від його експлуатації. Збільшуються прямі витрати на прове-

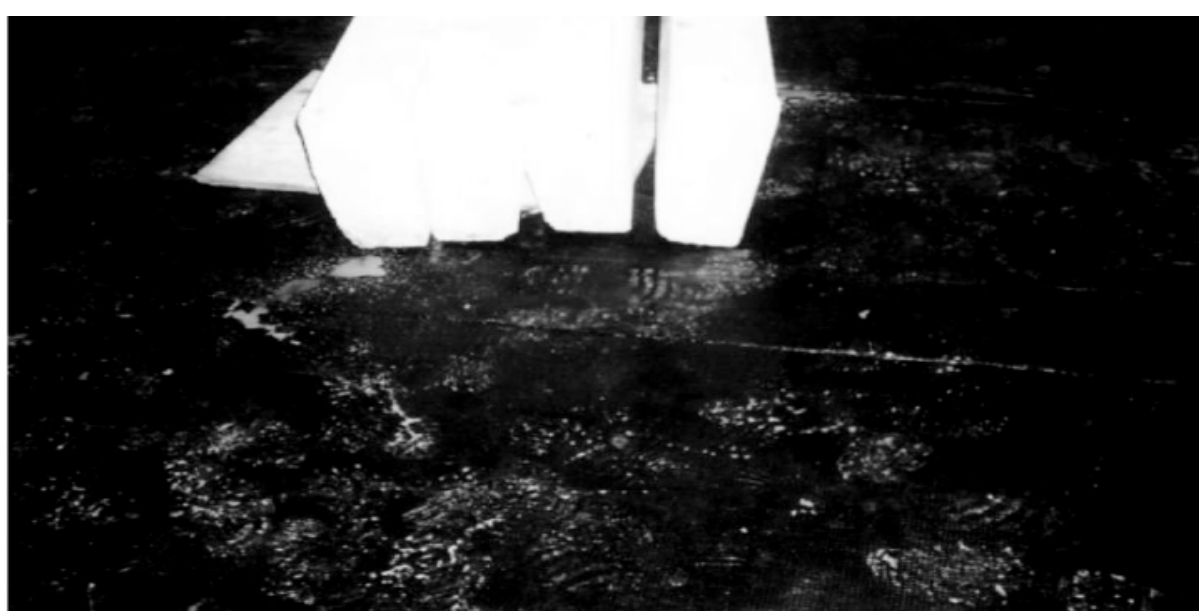

Рис. 2. Складування будівельних матеріалів на виконаній гідроізоляції 


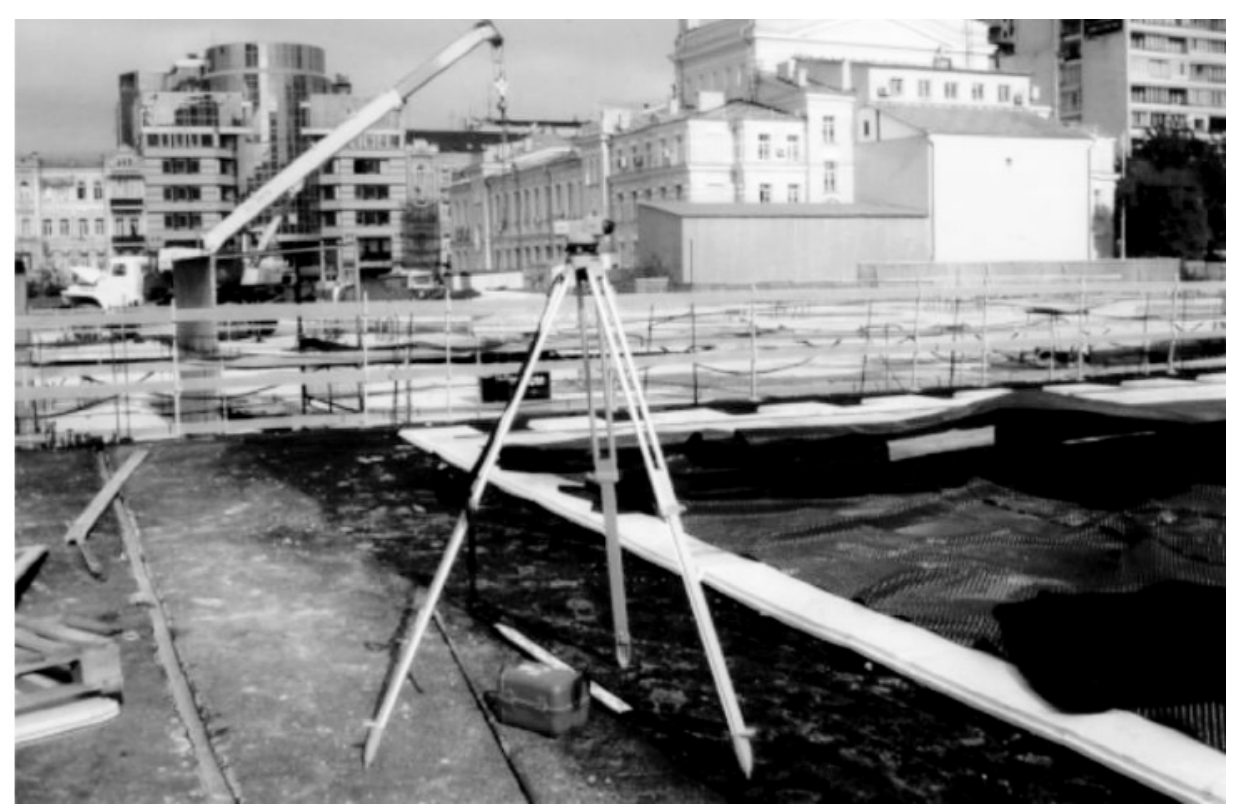

Рис. 3. Встановлення нівеліра на виконаній гідроізоляції

дення поточних і капітальних ремонтів.

\section{Висновки.}

В результаті проведеного аналізу існуючої ситуації в галузі проектування, улаштування та експлуатації гідроізоляції підземних конструкцій встановлений основний перелік ризиків пошкодження гідроізоляції, утворення дефектів, що завдають значної шкоди герметичності, довговічності і надійності такого відповідального будівельного елементу.
Відповідальний за експлуатацію будівлі або споруди повинен систематично проводити кваліфікований технічний огляд гідроізоляції і в обов'язковому порядку мати план з нанесеними дефектами та Перелік опису дефектів, що необхідні для прийняття рішень на ремонт.

За умови зменшення кількості ризиків можливо збільшити герметичність і надійність підземних конструкцій будівель і споруд.

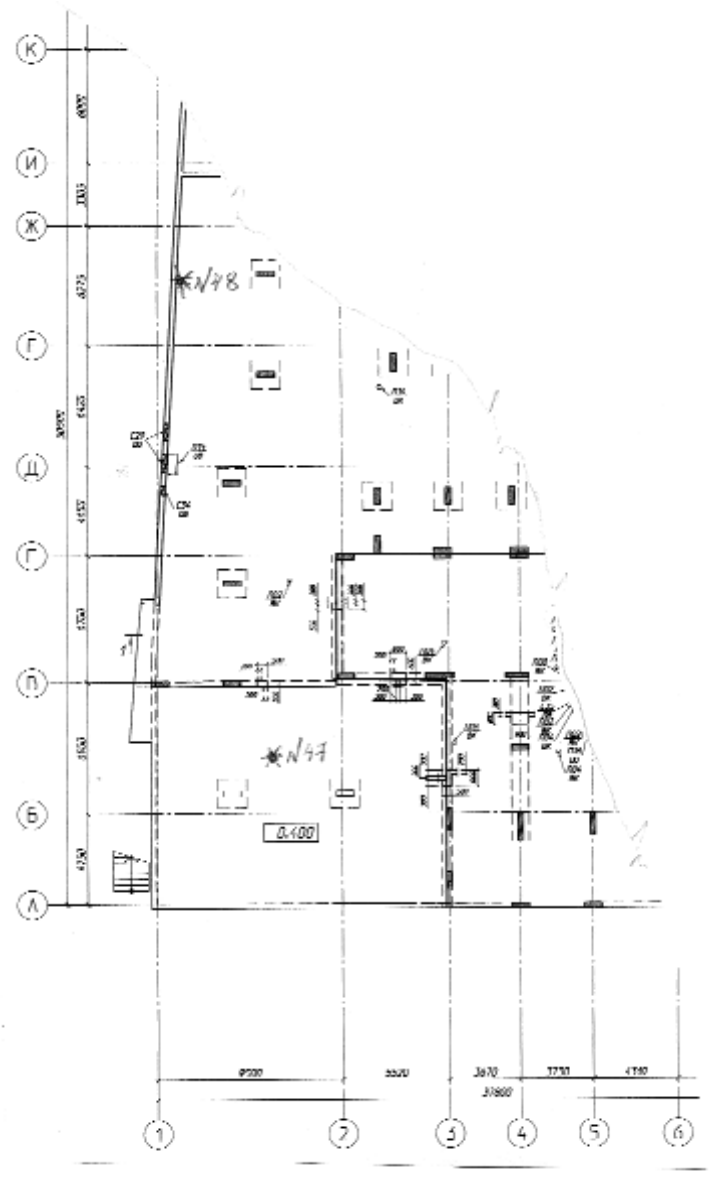

Рис. 4. Приклад плану днища будівлі, на якому зазначені дефекти гідроізоляції 


\section{Jimepamypa}

1. А.І. Гармаш; А.М. Галінський, к.т.н.; А.П. Баглай, к.т.н. Гідроізоляція будівель і споруд. Сучасні вимоги. К. НДІБВ, 2012.-120 с .: iлl.

2. А.І. Гармаш Система багатоступінчастої гідроізоляцій підземних частин будівель. Нові технологї в будівництві. №2.2002. К. НДІБВ.с.58-60.1 табл.2 мал.

3. С.К. Карапузов. Технологічні основи підвищення експлуатаційної ефективності систем гідроізоляції.-К. Виша освіта.2-13.-304 с .: іл.

4. В.В. Козлов, А.М. Чумаченко. Гідроізолячія в сучасному будівництві. АСВ. №2.2003.-120 с.

5. В.М. Покровський. Гідроізолячійні роботи-М. Стройиздат, 1985.-320 с.: іл.

6. С.Н. Попченко. Гідроізолячія споруд і будівель.-Л. Стройиздат, 981.-304 c.

7. Н.Г. Ярмоленко, Л.І. Іскра. Довідник по гідроізолячійним матеріалам для будівництва.-К. Будівельник, $1979 .-160$ с.

\section{Referernce}

1. AI Garmash; AM Galinsky, Ph.D .; AP Bagley, Ph.D. Waterproofing of buildings and structures. Modern requirements. K. NDIBV, 2012.-120 pp.: Ill.

2. AI Garmash The system of multistage waterproofing of underground parts of buildings. New technologies in construction. 2002/2002. K. NDIBV.c.58-60.1 table.2 picture

3. E.K. Karapuzov Technological bases for increasing the operational efficiency of waterproofing systems. -K. Higher education.2-13.-304 pp.: Ill.

4. V.V. Kozlov, AM Chumachenko Waterproofing in modern construction. DIA №2.2003.-120 p.

5. V.M. Pokrousky Hydro-insulating works-M. Stroyizdat, 1985.-320 pp .: Il.

6. SN Popcenko Waterproofing of buildings and buildings. -L. Stroyizdat, 981-304 pp.

7. NG Yarmolenko, LI Spark. Handbook for waterproofing materials for construction. -K. Budivelnik, 1979.-160 p.

А.И. Гармаш, ГП “НИИСП”, г. Киев

\section{ОСНОВНЫЕ ОШИБКИ ПРИ ПРОЕКТИРОВАНИИ И ВЫПОЛНЕНИИ ГИДРОИЗОЛЯЦИИ ПОДЗЕМНОЙ ЧАСТЕЙ ЗДАНИЙ И СООРУЖЕНИЙ}

Аннотация. В статье приведен перечень основньх ошибок при проектировании, устройстве гидроизоляиии подземных конструкиий зданий и сооружений. Проанализированы причины пояеления ошибок и методы их уменьшения или избавления от них.

Ключевые слова: гидроизоляция, дефекты гидроизоляции, протекания, гидроизоляция повыщенной надежности.

O.I. Garmash, The state "Research institute of building production" (NDIBV), Kyiv

\section{MAIN MISTAKES FOR DESIGN AND IMPLEMENTATION OF HYDRO INSULATION OF HOUSEHOLD PARTS OF BUILDINGS AND SPORTS}

Abstract. The article gives a list of the main mistakes in the design, installation of waterproofing of underground structures of buildings and structures. The reasons for the emergence of mistakes and methods of their reduction or elimination from them are analyzed.

Keywords: waterproofing, defects of waterproofing, leakage, waterproofing of increased reliability. 